14 Cooper RG, Edwards RHT, Gibson H, Stokes M. Human muscle fatigue: frequency dependence of excitation and force generation. $f$ Physiol 1988;397:585-99.

15 Cooper RG, Stokes MJ, Edwards RHT, Stark RD. Absence of excess peripheral muscle fatigue during $\beta$ adrenoceptor blockade. Br f Clin Pharm 1988:25:405-16.

16 Astrand I. Aerobic work capacity in men and women with special reference to age. Acta Physiol Scand 1960;169(suppl):45-60.

17 Chapman SJ, Edwards RHT, Greig C, Rutherford O. Practical application of the twitch interpolation technique for the study of voluntary contraction of the quadriceps muscle in man. $\mathscr{7}$ Physiol 1984;353:3P.

18 Wiles CM, Young A, Jones DA, Edwards RHT. Relaxation rate of constituent muscle fibre types in human quadriceps. Clin Sci 1979;56:47-57.
mus

9 Edwards RHT. Physiological analysis of skeletal muscle weakness and fatigue. Clin Sci Mol Med 1978;54:463-70.

20 Edwards RHT, Hill DK, Jones DA, Merton PA. Fatigue of long duration in human skeletal muscle after exercise. $\mathcal{F}$ Physiol 1977;272:769-78.

21 Basmajian JV. Re-education of vastus medialis; a misconception. Arch Phys Med Rehabil 1970;51:245-7.

22 Stokes M, Young A. The contribution of reflex inhibition to arthrogenous muscle weakness. Clin Sci 1984;67:7-14.
23 Woods JJ, Furbush F, Bigland-Ritchie B. Evidence for a fatigue-induced reflex inhibition of motoneuron firing rates. F Neurophysiol 1987:58:125-37. 24 Ho-Yeu DO, Carrington D, Armstrong AA. Myalgic encephalomyelitis and alpha-interferon. Lancet 1988;i:125.

25 Friman G, Schiller HH, Schwartz MS. Disturbed neuromuscular transmission in viral infections. Scand f Infect Dis 1977;9:99-103.

26 Friman G. Effect of acute infectious disease on isometric muscle strength. Scand f Clin Lab Invest 1977;37:303-8.

27 Friman G. Effect of acute infectious disease on human isometric muscle endurance. Upsala J Med Sci 1978;83:105-8.

28 Edwards RG, Lippold OCJ. The relation between force and integrated electrical activity in fatigued muscle after exercise. $\mathcal{F}$ Physiol 1956;132: 677-8

29 Komi PV, Viitalaso JT. Changes in motor unit activity and metabolism in human skeletal muscle during and after repeated eccentric and concentric contractions. Acta Physiol Scand 1977;100:246-54.

30 Gandevia SC, McCloskey DI. Interpretation of perceived motor commands by reference to afferent signals. $\mathcal{F}$ Physiol 1978;283:493-9.

31 Savage RA, Stokes MJ, Reilly T, Edwards RHT. Increased perception of effort with muscle fatigue. Int $\mathcal{f}$ Rehab Res (in press).

(Accepted 19 Julv 1988)

\title{
Prevention of gastroduodenal damage induced by non-steroidal anti-inflammatory drugs: controlled trial of ranitidine
}

\author{
R S B Ehsanullah, M C Page, G Tildesley, J R Wood
}

\section{Abstract}

Objective-To evaluate the prophylactic effect of ranitidine $150 \mathrm{mg}$ twice daily in patients requiring one of the following non-steroidal anti-inflammatory drugs: naproxen, piroxicam, diclofenac, and indomethacin. In addition, risk factors were studied in order to help in targeting of such treatment to specific groups of patients.

Design-Double blind, placebo controlled, randomised, parallel group with endoscopic assessments at 0,4 , and 8 weeks.

Setting-Multicentre outpatient study at secondary referral centres in five European countries.

Patients -297 patients with rheumatoid arthritis or osteoarthritis over the age of 18 without lesions in the stomach and duodenum at baseline endoscopy (after one week without taking non-steroidal antiinflammatory drugs). Those taking other antirheumatic agents, concomitant ulcerogenic drugs, or treatment for peptic ulcers within the previous 30 days were excluded. Age, sex, arthritic disease, and type of non-steroidal anti-inflammatory drug used were comparable in the two treatment groups. In all, 263 patients completed the trial.

Interventions-Ranitidine $150 \mathrm{mg}$ twice daily or placebo (plus the selected non-steroidal antiinflammatory drug) was prescribed within five days after the baseline endoscopy for two consecutive periods of four weeks. Paracetamol was permitted during the study, but not antacids. Patients were withdrawn if the most severe grade of damage (including ulceration) was found at the four week endoscopy or when indicated, or with lesser damage at the investigator's discretion.

End point-Frequency of gastric and duodenal ulceration or lesions, or both.

Measurements and main results - The cumulative incidence of peptic ulceration by eight weeks was $10.3 \%(27 / 263)$; 2 out of $135(1.5 \%)$ developed duodenal ulceration in the ranitidine group, compared with 10 out of $126(8 \%)$ taking placebo. The frequency of gastric ulceration was the same $(6 \%)$ for the two groups at eight weeks. Though significantly fewer gastric lesions developed in the ranitidine group by four weeks, this difference was not evident by eight weeks. The frequency of non-ulcerative lesions in the duodenum did not differ greatly for the two groups at either time point. Twelve out of 75
(16\%) patients taking piroxicam developed peptic ulceration, of whom two thirds had duodenal ulceration. Patients with a history of peptic ulcer were particularly susceptible to recurrent ulceration, against which ranitidine offered some protection.

Conclusions-Ranitidine $150 \mathrm{mg}$ twice daily significantly reduced the incidence of duodenal ulceration but not gastric ulceration when prescribed concomitantly with one of four commonly used non-steroidal anti-inflammatory drugs.

\section{Introduction}

Non-steroidal anti-inflammatory drugs for the treatment of arthritis are the most widely prescribed group of drugs world wide. In the United Kingdom 23 million prescriptions were issued in 1986 for this group of drugs, accounting for around $5 \%$ of all NHS prescriptions. These drugs, however, account for $25 \%$ of all the suspected adverse drug reactions reported to the United Kingdom Committee on Safety of Medicines each year and 21\% reported to the United States Food and Drug Administration. ${ }^{12}$ The commonest and most serious of these reactions are gastrointestinal..$^{3-5} \mathrm{Up}$ to $60 \%$ of patients taking these drugs report dyspepsia, ${ }^{5-7}$ but this has not proved to be a reliable guide to the presence of gastroduodenal lesions. ${ }^{8-12}$

Aspirin causes gastroduodenal damage in more than $80 \%$ of subjects, ${ }^{13} 14$ varying from acute microscopic gastric changes ${ }^{15}$ to potentially more serious chronic gastric ulceration or haemorrhage..$^{76-18}$ In a large prospective study gastric lesions were found in a third of patients taking non-steroidal anti-inflammatory drugs for a year and in half of those receiving two or more such drugs. ${ }^{8}$ Langman calculated a rate of one episode of gastrointestinal haemorrhage per 6000 prescriptions for non-steroidal anti-inflammatory drugs $^{19}$; estimates for attributable mortality in the United Kingdom range from $200^{20}$ to over $4000^{21}$ deaths annually. Epidemiological data also point to rising rates of ulcer perforation in the elderly, partly attributable to the increased use of this group of drugs. ${ }^{22}$ Other centres in the United Kingdom have noted this association, ${ }^{23-25}$ though some studies from Australia and America do not show similar trends. ${ }^{26} 27$

Attempts to decrease the risks associated with antiinflammatory treatment by using enteric coated formulations, suppositories, or prodrugs have not 
solved this problem. Antiulcer drugs are often prescribed concomitantly, though little is known about their efficacy and advantages. Theoretically any decrease in acid secretion should minimise gastroduodenal damage and ease recovery. In a study on bleeding induced by aspirin, inhibition of acid secretion represented the best strategy to reduce gastric mucosal bleeding. ${ }^{28}$ In other studies ranitidine and cimetidine protected against damage induced by aspirin in volunteers. ${ }^{29-32}$

We evaluated the protection given by ranitidine 150 mg twice daily in a large population of patients requiring non-steroidal anti-inflammatory drugs. In addition, we studied risk factors to target treatment to specific subgroups of patients.

\section{Patients and methods}

Patients with rheumatoid arthritis or osteoarthritis, aged over 18, and requiring treatment with nonsteroidal anti-inflammatory drugs were recruited into a double blind trial conducted in 18 centres in five countries-France, Ireland, Norway, Sweden, and the United Kingdom. Criteria for inclusion were verification by endoscopy of a "clean" stomach and duodenum as defined by a score of zero on a grading scale modified from that of Lanza et al ${ }^{\prime}$ (table I) and at least one week without taking non-steroidal anti-inflammatory drugs before entry to the trial. Patients taking gold, penicillamine, azathioprine, or chloroquine were excluded. Other exclusion criteria comprised concomitant use of ulcerogenic drugs, treatment for peptic ulcers during the preceding 30 days (except for low dose antacids), use of corticosteroids, pregnancy or lactation, gastrointestinal malignancy, dysphagia, rheumatoid arthritis of the cervical spine, and impairment of liver or kidney function. Patients gave their informed consent to the study, which was approved by ethics committees in each country. The trial was conducted in accordance with the Declaration of Helsinki.

Patients were allocated on a double blind seyuential basis to receive treatment with either ranitidine $150 \mathrm{mg}$ twice daily or a matching placebo tablet twice daily according to a predetermined randomisation code balanced in blocks of 10 generated by Glaxo Group Research Limited. Non-steroidal anti-inflammatory drug treatment was started concomitantly with each centre using one of the following four agents at doses not less than those indicated: naproxen $(750 \mathrm{mg} /$ day $)$, piroxicam $(20 \mathrm{mg} /$ day $)$, diclofenac $(100 \mathrm{mg} /$ day $)$, or indomethacin $(100 \mathrm{mg} /$ day $)$. Treatment was started within five days after the initial endoscopy. Use of paracetamol, but not antacids, was permitted during the study period. All drugs for the trial were prepacked and supplied by the company.

Endoscopy was repeated after four weeks; patients with little or no gastroduodenal damage at this examination continued treatment for a further four weeks and were then reassessed and examined by endoscopy. Patients with grade 4 gastroduodenal damage were withdrawn from the study and those with grade 3 either continued or were withdrawn at the discretion of the investigator. Biopsy was performed on gastric ulcers to exclude malignancy. Any patient returning for an unscheduled visit because of dyspepsia was encouraged to undergo a gastroscopy.

\section{STATISTICAL METHODS}

Calculation of the sample size was based on the proportion of patients showing clinically important gastroduodenal damage when examined by endoscopy. This was prospectively defined as grade 2,3 , or 4 on a modified Lanza scale and was expected to develop in $30 \%$ of patients receiving the placebo. A sample size of 320 patients was chosen to give a $90 \%$ power of detecting a reduction to $15 \%$ on ranitidine at $p \leqslant 0.05$. Patients were included in the analysis of gastroduodenal damage if they had undergone a follow up endoscopy up to and including four weeks and up to and including eight weeks. The eight week analyses were cumulative, incorporating all four week data.

The statistical analysis of the trial examined two aspects. The first of these, and the primary objective of the trial, was to compare the incidence of clinically important gastroduodenal damage in the ranitidine and placebo groups. The damage to the stomach and duodenum was graded and analysed separately. The proportion of patients with evidence of damage was analysed using the Mantel-Haenszel $\chi^{2}$ test without continuity correction. ${ }^{33}$ The odds ratio (odds of developing damage on placebo/odds of developing damage on ranitidine) was estimated together with 95\% confidence limits. ${ }^{34}$ Further analyses were performed stratified for various risk factors but they led to similar levels of significance and are not reported here. The Mantel-Haenszel approach also included tests for treatment by risk factor interactions and the one interaction detected is reported. The incidence of ulcers was analysed using Fisher's exact test as the numbers were small. All significance tests were two tailed.

The second aspect of the analysis examined the importance in terms of gastroduodenal damage of various risk factors irrespective of trial treatment. The different levels of each risk factor were initially compared using the Mantel-Haenszel test, grouping the trial treatments. The results were confirmed using logistic regression to allow for the confounding effects of other risk factors. ${ }^{35}$

\section{Results}

There were 297 patients entered into the trial. Thirty four patients were excluded at four weeks because they did not have an endoscopy at that time. These comprised 14 taking ranitidine, of whom five

TABLE II - Demographic details of patients in trial

\begin{tabular}{|c|c|c|}
\hline & Ranitidine & Placebo \\
\hline No of patients & 137 & 126 \\
\hline Sex (men:women) & $58: 79$ & $47: 79$ \\
\hline \multicolumn{3}{|l|}{ Age (years); } \\
\hline Mean $(\mathrm{SD})$ & $57(11)$ & $60(13)$ \\
\hline Range & $25-85$ & $22-87$ \\
\hline \multicolumn{3}{|l|}{ Smoking state: } \\
\hline None & 79 & 90 \\
\hline$<20$ cigarettes/day & 44 & 24 \\
\hline$\geqslant 20$ cigarettes/day & 10 & 5 \\
\hline Cigar or pipe & 4 & 7 \\
\hline \multicolumn{3}{|l|}{ Alcohol intake: } \\
\hline None & 65 & 76 \\
\hline$<50$ g/day & 71 & 50 \\
\hline$\geqslant 50 \mathrm{~g} /$ day & 1 & 0 \\
\hline \multicolumn{3}{|l|}{ Arthritic disease: } \\
\hline Osteoarthritis & 101 & 96 \\
\hline Rheumatoid arthritis & 34 & 28 \\
\hline Other & 2 & 2 \\
\hline Median duration (range) of arthritis (years) & $8(0-50)$ & $6(0-45)$ \\
\hline Previous dyspepsia & 71 & 72 \\
\hline Previous peptic ulcer & 11 & 11 \\
\hline Previous $\mathrm{H}_{2}$ receptor antagonist & 20 & 21 \\
\hline \multirow{2}{*}{$\begin{array}{l}\text { No previous use of non-steroidal } \\
\text { anti-inflammatory drugs }\end{array}$} & & \\
\hline & 60 & 46 \\
\hline
\end{tabular}

failed to return or refused to continue and nine were withdrawn without endoscopy because of adverse reactions, and 20 taking placebo, of whom 14 and six fell into these two categories respectively. Of the remaining 263 patients, 137 received ranitidine and 126 placebo. The two treatment groups were comparable with respect to patient demography (table II). The non-steroidal anti-inflammatory drugs used during the trial were naproxen (161 patients), piroxicam (75), diclofenac (17), and indomethacin (10).

By counting ranitidine and placebo tablets returned 
at four weeks we judged that $75 \%$ of patients took more than $90 \%$ of their oral treatment.

\section{GASTRODUODENAL DAMAGE}

After four weeks of treatment there were significantly fewer patients with gastric mucosal lesions (including ulcers) in the ranitidine treatment group than in the placebo group ( $15 \% v 25 \%$, odds ratio 1.9 , $95 \%$ confidence interval 1.0 to 3.5 (table III)). No

TABLE III-Numbers (percentages) of patients with gastric and duodenal damage after four and eight weeks

\begin{tabular}{|c|c|c|c|c|}
\hline & \multicolumn{2}{|c|}{ Stomach } & \multicolumn{2}{|c|}{ Duodenum } \\
\hline & $\begin{array}{c}\text { Ranitidine } \\
(\mathrm{n}=137)\end{array}$ & $\begin{array}{l}\text { Placebo } \\
(n=126)\end{array}$ & $\begin{array}{c}\text { Ranitidine } \\
(\mathrm{n}=137)\end{array}$ & $\begin{array}{c}\text { Placebo } \\
(n=126)\end{array}$ \\
\hline \multicolumn{5}{|c|}{ Ulcers } \\
\hline $\begin{array}{l}\text { Four weeks } \\
\text { Eight weeks }\end{array}$ & $\begin{array}{ll}4 & (3) \\
8 & (6)\end{array}$ & $\begin{array}{ll}6 & (5) \\
7 & (6)\end{array}$ & $\begin{array}{ll}2 & (1.5) \\
2 & (1.5)\end{array}$ & $\begin{array}{ll}10 & (8)^{\star} \\
10 & (8)^{\star}\end{array}$ \\
\hline \multicolumn{5}{|c|}{ Grades $2-4$} \\
\hline $\begin{array}{l}\text { Four weeks } \\
\text { Eight weeks }\end{array}$ & $\begin{array}{l}21(15) \\
38(28)\end{array}$ & $\begin{array}{l}32(25) \dagger \\
40(32)\end{array}$ & $\begin{array}{l}13(9) \\
17(12)\end{array}$ & $\begin{array}{l}16(13) \\
17(13)\end{array}$ \\
\hline
\end{tabular}

$p=0.024$ (Fisher's exact test)

tp $=0.042$ (Mantel-Haenszel $\chi^{2}$ test $)$

additional benefit was observed in the stomach after continuing treatment for a further four weeks. After four weeks' treatment gastric ulceration was found in $3 \%$ of those receiving ranitidine and $5 \%$ of those taking placebo $(p=0.527)$ and in $6 \%$ in both treatment groups after eight weeks. In the duodenum there was a significantly lower frequency of ulceration in the ranitidine group than in the placebo group $(1.5 \% v 8 \%$, odds ratio $5 \cdot 8$, confidence interval $1 \cdot 4$ to $23 \cdot 6$ ) after four and eight weeks (when no new duodenal ulcers had formed). No patient developed both a gastric and a duodenal ulcer.

The overall incidence of gastric and duodenal ulceration was $16 \%(12 / 75)$ in patients receiving piroxicam, $9 \%(14 / 161)$ with naproxen, and $6 \%(1 / 17)$ with diclofenac. Piroxicam caused significantly more duodenal damage than naproxen at both four and eight weeks (table IV). In both ranitidine and placebo

TABLE IV - Numbers (percentages) of patients with duodenal damage after treatment with naproxen or piroxicam

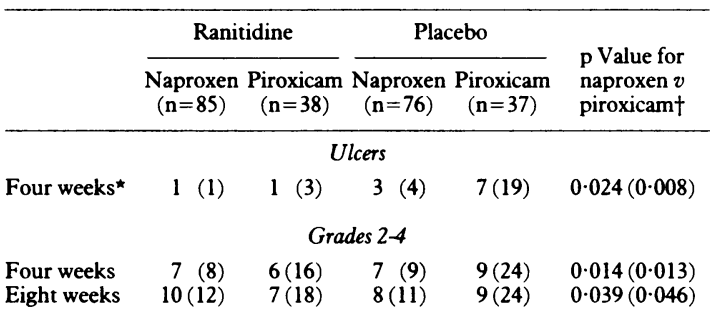

*No further patients had developed duodenal ulceration by eight weeks. †Value in parenthesis is after adjusting for trial treatment, sex, history of ulcers, smoking, and arthritis type.

groups combined there were four (2\%) duodenal ulcers in those treated with naproxen and eight $(11 \%)$ in those given piroxicam. There was no significant difference in ulceration of the stomach between patients taking these two drugs; eight $(5 \%)$ and $10(6 \%)$ patients developed gastric ulcers during treatment with naproxen, and two (3\%) and four (5\%) with piroxicam after four and eight weeks' treatment respectively. At four weeks 7 out of 41 (17\%) women had duodenal and gastric ulcers associated with piroxicam compared with 3 out of $34(9 \%)$ men, whereas at eight weeks the frequency of ulcers was more balanced $(17 \%$ women compared with 5 out of $34(15 \%)$ men). In the naproxen treatment group 4 out of 96 and 6 out of 96 women had peptic ulcers (gastric only) at four and eight weeks respectively, compared with 8 out of $65(12 \%)$ men at both time points.

\section{RISK FACTORS}

The 22 patients with a history of peptic ulceration showed a significantly greater susceptibility to recurrent ulceration while taking non-steroidal antiinflammatory drugs and seemed to obtain greater protection with ranitidine than patients without a history of ulcers (table V).

TABLE $\mathrm{v}-$ Ulceration in patients with or without history of peptic ulcer. Values are numbers (percentages) of patients

\begin{tabular}{|c|c|c|c|c|c|}
\hline & \multicolumn{2}{|c|}{ Ranitidine } & \multicolumn{2}{|c|}{ Placebo } & \multirow{2}{*}{$\begin{array}{l}\text { p Value for } \\
\text { history } v \text { no } \\
\text { history }\end{array}$} \\
\hline & $\begin{array}{l}\text { History } \\
(\mathrm{n}=11)\end{array}$ & $\begin{array}{c}\text { No history } \\
(n=126)\end{array}$ & $\begin{array}{l}\text { History } \\
(\mathrm{n}=11)\end{array}$ & $\begin{array}{c}\text { No history } \\
(\mathrm{n}=115)\end{array}$ & \\
\hline $\begin{array}{l}\text { Four weeks } \\
\text { Eight weeks }\end{array}$ & $\begin{array}{l}1(9) \\
2(18)\end{array}$ & $\begin{array}{l}5(4) \\
8(6)\end{array}$ & $\begin{array}{l}5(45) \\
6(55)\end{array}$ & $\begin{array}{l}11(10) \\
11(10)\end{array}$ & $\begin{array}{l}0.011(<0.001) \\
0.001(<0.001)\end{array}$ \\
\hline
\end{tabular}

*Value in parenthesis is after adjusting for trial treatment, sex, smoking, arthritis type, and non-steroidal anti-inflammatory drug.

Duodenal damage (but not ulceration alone) was influenced by the patient's sex, smoking habit, type of non-steroidal anti-inflammatory drug, and type of arthritic disease but not by age, history of dyspepsia, or previous use of non-steroidal anti-inflammatory drugs. The incidence of duodenal damage in the women at both four (4\%) and eight weeks (6\%) was significantly less than that in men $(21 \%$ and $23 \%$ respectively; table VI). Furthermore, the women obtained significantly more protection from ranitidine than men (table VI) (test for treatment by sex interaction,

TABLE VI-Duodenal damage at four weeks for men and women, smokers and non-smokers, and patients with osteoarthritis and rheumatoid arthritis. Values are numbers (percentages) of patients

\begin{tabular}{|c|c|c|c|c|c|c|}
\hline & \multicolumn{2}{|c|}{ Ranitidine } & \multicolumn{2}{|c|}{ Placebo } & \multicolumn{2}{|c|}{$\begin{array}{l}\mathrm{p} \text { Values for } \\
\text { comparisons of } \\
\text { all patients }\end{array}$} \\
\hline & $\underset{(n=58)}{M e n}$ & $\begin{array}{l}\text { Women } \\
(n=79)\end{array}$ & $\begin{array}{c}\text { Men } \\
(n=47)\end{array}$ & $\begin{array}{l}\text { Women } \\
(n=79)\end{array}$ & & \\
\hline \multirow[t]{2}{*}{$\begin{array}{l}\text { Ulcers } \\
\text { Grades 2-4 }\end{array}$} & $\begin{array}{r}2(3) \\
13(22)\end{array}$ & $\begin{array}{l}0 \\
0\end{array}$ & $\begin{array}{l}5(11) \\
9(19)\end{array}$ & $\begin{array}{l}5(6) \\
7(9)\end{array}$ & $\begin{array}{c}0.303 \\
<0.001\end{array}$ & $\begin{array}{r}(0.145) \\
<0.001)\end{array}$ \\
\hline & $\begin{array}{l}\text { Smoker } \\
(n=58)\end{array}$ & $\begin{array}{c}\text { Non- } \\
\text { smoker } \\
(n=79)\end{array}$ & $\begin{array}{l}\text { Smoker } \\
(n=36)\end{array}$ & $\begin{array}{c}\text { Non- } \\
\text { smoker } \\
(n=90)\end{array}$ & & \\
\hline \multirow[t]{2}{*}{$\begin{array}{l}\text { Ulcers } \\
\text { Grades 2-4 }\end{array}$} & $\begin{array}{r}1(2) \\
11(19)\end{array}$ & $\begin{array}{l}1(1) \\
2(3)\end{array}$ & $\begin{array}{l}5(14) \\
8(22)\end{array}$ & $\begin{array}{l}5(5) \\
8(9)\end{array}$ & $\begin{array}{r}0.449 \\
<0.001\end{array}$ & $\begin{array}{l}(0.259) \\
(0.003)\end{array}$ \\
\hline & $\begin{array}{c}\text { Osteo- } \\
\text { arthritis } \\
(n=101)\end{array}$ & $\begin{array}{c}\text { Rheumatoid } \\
\text { arthritis } \\
(n=34)\end{array}$ & $\begin{array}{c}\text { Osteo- } \\
\text { arthritis } \\
(n=96)\end{array}$ & $\begin{array}{c}\text { Rheumatoid } \\
\text { arthritis } \\
(n=28)\end{array}$ & & \\
\hline $\begin{array}{l}\text { Ulcers } \\
\text { Grades 2-4 }\end{array}$ & $\begin{array}{r}1(1) \\
11(11)\end{array}$ & $\begin{array}{l}1(3) \\
2(6)\end{array}$ & $\begin{array}{l}10(10) \\
16(17)\end{array}$ & $\begin{array}{l}0 \\
0\end{array}$ & $\begin{array}{l}0.345 \\
0.023\end{array}$ & $\begin{array}{l}(0.624) \\
(0.104)\end{array}$ \\
\hline
\end{tabular}

*Value in parenthesis is after adjusting for trial treatment, sex, history of ulcers, smoking, and arthritis type.

$p=0.012$ at four weeks; $p=0.039$ at eight weeks). The incidence of duodenal mucosal damage in the women was independent of age, though four of the duodenal ulcers occurred in those over 55 and only one in those under 55. Smokers showed significantly more duodenal damage than non-smokers irrespective of treatment, and patients with osteoarthritis showed significantly more duodenal damage than those with rheumatoid arthritis (table VI). None of these factors, however, seemed to influence the degree of gastric damage, though the frequency of such damage in patients with osteoarthritis taking placebo was $29 \%$ compared with $11 \%$ in those with rheumatoid arthritis.

\section{GASTROINTESTINAL SYMPTOMS}

The prevalence and severity of gastrointestinal symptoms (epigastric pain, heartburn, nausea, and vomiting) were similar for the two treatment groups before the trial and at four and eight weeks-for 
example, before the trial $18 \%$ of all the patients presented with some degree of epigastric pain; at four and eight weeks $25 \%$ and $21 \%$ respectively had this symptom. This trial was not designed to evaluate patients with symptoms; among the patients with severe gastroduodenal damage graded 3 and 4 at four weeks, however, $79 \%$ had symptoms whereas among those with lesser grades of damage $43 \%$ had symptoms $(\mathrm{p}<0.001)$.

\section{ADVERSE REACTIONS}

Adverse reactions were reported by 25 of the 151 (17\%) patients taking ranitidine and 22 of the 146 (15\%) patients taking placebo. Their distribution was comparable for the two treatment groups. Most reactions ( $43 \%$ and $64 \%$ respectively) were gastrointestinal symptoms. A total of 37 patients, 19 in the ranitidine group and 18 in the placebo group, withdrew from the study because of adverse reactions. Of these, 10 and 13 patients in the two groups, respectively, discontinued treatment because of adverse gastrointestinal effects. Other reasons for withdrawal included headache (eight patients), dizziness (three), angina (two), disturbed sleep (two), depression (one), and rash (one).

\section{Discussion}

The results of this prospective trial, the largest of its kind to date, show that ranitidine $150 \mathrm{mg}$ twice daily administered over eight weeks to arthritic patients without gastroduodenal lesions taking non-steroidal anti-inflammatory drugs provides significant prophylaxis against the development of duodenal ulceration and gastric mucosal lesions during the first four weeks. There was no significant difference between the groups in the incidence of gastric ulceration but, despite the size of the trial, there were relatively few gastric ulcers in either group.

Selecting patients without lesions at the first endoscopy, a group possibly less susceptible to damage, may partly account for two thirds of the patients showing insufficient damage to enable any protective effect of ranitidine to be detected. Inclusion of such patients may also have influenced the results in the studies on prophylaxis reported by Roth ${ }^{36}$ and Bianchi Porro. ${ }^{37}$ The failure of Roth to show a protective effect with cimetidine may have been because of less than adequate acid inhibition. Furthermore, since the clinical relevance of mucosal lesions in these studies is not clear, basing conclusions on the evaluation of actual ulceration is preferable.

In our study few ulcers were seen between four and eight weeks and none in the duodenum, suggesting possible adaptation of the mucosa, as shown in some studies of aspirin and indomethacin treatment. ${ }^{1338} 39$ Damage induced by non-steroidal anti-inflammatory drugs has generally been assumed to occur in the stomach. Several studies, however, have implicated the duodenum as an alternative or additional site. ${ }^{101131}$ We noted a higher incidence of duodenal ulceration (mostly in patients receiving piroxicam) than of gastric ulceration. Piroxicam was associated with a higher incidence of peptic ulceration than was naproxen (16\% and $9 \%$ respectively), and treatment with piroxicam was associated with eight of the 12 duodenal ulcers that developed during the study. Several anecdotal reports have implied that piroxicam causes more ulcers than other non-steroidal anti-inflammatory drugs, especially in the elderly, ${ }^{40-43}$ though such conclusions have been disputed. ${ }^{14}$ Husby compared piroxicam with naproxen in the treatment of over 2000 patients with osteoarthritis over 12 weeks, and gastrointestinal side effects were reported by $31 \%$ of patients taking piroxicam and $38 \%$ of those taking naproxen. The incidence of serious side effects - such as peptic ulcer or gastrointestinal haemorrhage - was reported as only $1 \%$ for both drugs. These patients, however, were not subjected to routine gastrointestinal endoscopy. ${ }^{45}$

We showed that patients with a history of peptic ulcers not only were more susceptible to recurrent ulceration from non-steroidal anti-inflammatory drugs than patients without such a history (an observation also made by Caruso and Bianchi Porro ${ }^{8}$ and Larkai et $\left.a l^{12}\right)$ but also seemed to benefit more from ranitidine prophylaxis. Doctors are advised not to prescribe non-steroidal anti-inflammatory drugs to patients with a history of peptic ulcer disease or abdominal symptoms. ${ }^{23}$ If they have to take these drugs they may particularly benefit from concomitant treatment with ranitidine.

Over four times as many of the men as the women sustained duodenal damage but the women obtained significantly more protection from ranitidine. This was confirmed when the possible confounding effects of smoking and other factors were taken into account. Age did not appear to be a risk factor. Clinch $e t$ al have reported an association between use of non-steroidal anti-inflammatory drugs and duodenal ulceration in elderly women, ${ }^{46}$ and our data showed increased duodenal ulceration in the women over 55 compared with those below this age.

Patients with rheumatoid arthritis experienced significantly less duodenal and gastric damage than those with osteoarthritis, though Caruso and Bianchi Porro ${ }^{8}$ and Larkai $e t a l^{12}$ noted similar effects in both. There was no serious gastrointestinal illness in either group in our study. Those adverse reactions that occurred were probably because of the non-steroidal anti-inflammatory drugs.

We have shown that patients with a history of peptic ulcers are at increased risk of recurrent ulceration while non-steroidal anti-inflammatory drugs are being taken. Protection against duodenal ulceration, particularly that associated with piroxicam, was evident in those patients taking ranitidine, though some ulceration still occurred. Further work is needed to substantiate these findings and to evaluate whether greater suppression of acidity may provide any additional benefit.

We thank the following investigators who participated in this trial: France-Professor J P Capron, Professor M Cerf; Ireland-Dr J E Hegarty; Norway-Dr R Skjoelingstad, Dr $M$ Stokkeland, DrM Toender; Sweden-Dr H Abrahamsson, Dr R Befrits, Dr C-H Floren, Dr M Hradsky, Dr A Norrby, Dr B Jaup; United Kingdom-Dr M E Denyer, Dr E Elias, Dr K Matthewson, Dr T C Northfield, Dr F A O'Connor, Dr K G Porter, Dr P I Reed.

1 Rossi CA, Hus JP, Faich GA. Ulcerogenicity of piroxicam: an analysis of spontaneously reported data. $\mathrm{Br}$ Med $\mathcal{F}$ 1987; 129:147-50.

2 Anonymous. CSM update. Non-steroidal anti-inflammatory drugs and serious gastrointestinal adverse reactions. 1. Br Med f 1986;292:614.

3 Anonymous. CSM update. Non-steroidal anti-inflammatory drugs and serious gastrointestinal adverse reactions. 2. Br Med f 1986;292:1190-1.

4 Pemberton RE, Strand LJ. A review of upper gastrointestinal effects of the newer non-steroidal anti-inflammatory agents. Dig Dis Sci 1979;24:53-64.

5 O'Brien WM. Pharmacology of non-steroidal anti-inflammatory drugspractical review for clinicians. Am $\mathcal{F}$ Med 1983;75:32-9.

6 Coles LS, Fries JF, Kraines RG, Roth SH. From experiment to experience: side effects of non-steroidal anti-inflammatory drugs. Am Y Med 1983;74: 820-8.

7 Silvoso GR, Ivey $\mathrm{KJ}$, Butt JH, et al. Incidence of gastric lesions in patients with rheumatic disease on chronic aspirin therapy. Ann Intern Med 1979;91: rheuma.

8 Caruso I, Porro GB. Gastroscopic evaluation of anti-inflammatory agents. BrMed f 1980;280:75-8.

9 Lanza FL, Royer GL, Nelson RS, Chen TT, Seckman CE, Rack MF. A comparative endoscopic evaluation of the damaging effects of non-steroidal anti-inflammatory agents on the gastric and duodenal mucosa. Am $\mathcal{f}$ Gastroenterol 1981;75:17-21.

10 Mellem H, Stave R, Myren J, et al. Symptoms in patients with peptic ulcer and hematemesis and/or melena related to the use of non-steroid antiinflammatory drugs. Scand f Gastroenterol 1985;20:1246-8.

11 Collins AJ, Davies J, Dixon AStJ. Contrasting presentation and findings between patients with rheumatic complaints taking non-steroidal antiinflammatory drugs and a general population referred for endoscopy. $\mathrm{Br} \mathcal{J}$ Rheumatol 1986:25:50-3. 
12 Larkai EN, Smith JL, Lidsky MD, Graham DY. Gastroduodenal mucosa an dyspeptic symptoms in arthritic patients during chronic non-steroidal ant inflammatory drug use. Am $\mathcal{F}$ Gastroenterol 1987;82:1153-8.

13 O'Laughlin JC, Hoftiezer JW, Ivey KJ. Effect of aspirin on normal human stomach. Scand f Gastroenterol [S uppl] 1981;67:211-4

14 Hoftiezer JW, O'Laughlin JC, Ivey KJ. Effects of 24 hours of aspirin Bufferin, paracetamol and placebo on normal human gastroduodenal mucosa. Gut 1982;23:692-7.

15 Baskin WN, Ivey KJ, Krause W, Jeffrey E, Gemmell RT. Aspirin induced ultrastructural changes in human gastric mucosa. Ann Intern Med 1976;85 294-303.

16 Levy $M$. Aspirin use in patients with major upper gastrointestinal bleeding and peptic ulcer disease. $N$ Engl $f$ Med 1974;290:1158-62.

17 Rees WD, Turnberg LA. Reappraisal of the effects of aspirin on the stomach. Lancet 1980;ii:410-3.

18 Duggan JM, Dobson AJ, Johnson H, Fahey P. Peptic ulcer and non-steroidal anti-inflammatory agents. Gut 1986;27:929-33.

19 Langman MJS. Peptic ulcer complications and the use of non-aspirin non-steroidal anti-inflammatory drugs. Adverse Drug Reaction Bulletin 1986;120:448-5

20 Somerville K, Faulkner G, Langman M. Non-steroidal anti-inflammatory drugs and bleeding peptic ulcer. Lancet 1986;i:462-4.

21 Cockel R. Non-steroidal anti-inflammatory drugs-should every prescription carry a government health warning? Gut 1987;28:515-8

22 Walt R, Katschinski B, Logan R, Ashley J, Langman M. Rising frequency of ulcer perforation in elderly people in the United Kingdom. Lancet 1986; ; 489-92.

23 Coggon D, Lambert P, Langman MJS. 20 years of hospital admissions for peptic ulcer in England and Wales. Lancet 1981; ; : 1302-4.

24 Collier DStJ, Pain JA. Non-steroidal anti-inflammatory drugs and peptic ulcer perforation. Gut 1985;26:359-63.

25 Armstrong CP, Blower AL. Non-steroidal anti-inflammatory drugs and life threatening complications of peptic ulceration. Gut 1987;28:527-32.

26 Henry DA, Johnston A, Dobson A, Duggan J. Fatal peptic ulcer complications and the use of non-steroidal anti-inflammatory drugs, aspirin, and corticosteroids. $B r$ Med $\mathcal{F}$ 1987;295:1227-9.

27 Jick SS, Perera DR, Walker AM, Jick H. Non-steroidal anti-inflammator drugs and hospital admission for perforated peptic ulcer. Lancet 1987;ii:380.

28 Hawkey CJ, Prichard PJ, Somerville KW. Strategies for preventing aspirininduced gastric bleeding. Scand f Gastroenterol [Suppl] 1986;21:170-3.
29 Kimmey MB, Silverstein FE, Saunders DR, Chapman RC. Reduction of endoscopically assessed acute aspirin-induced gastric mucosal injury with cimetidine. Dig Dis Sci 1987;32:851-6.

30 Hogan DL, Thomas FJ, Isenberg JI. Cimetidine decreases aspirin-induced gastric mucosal damage in humans. Alimentary Pharmacology Therapeutic 1987;1:383-90.

31 Berkowitz JM, Adler SN, Sharp JT, Warner CW. Reduction of aspirin induced gastroduodenal mucosal damage with ranitidine. $\mathcal{F}$ Clin Gastroenterol 1986;8:377-80.

32 Berkowitz JM, Rogenes PR, Sharp JT, Warner CW. Ranitidine protects against gastroduodenal mucosal damage associated with chronic aspirin therapy. Arch Intern Med 1987;147:2137-9.

33 Fleiss JL. Statistical methods for rates and proportions. Chichester: Wiley, 1973.

34 Morris JA, Gardner MJ. Calculating confidence intervals for relative risks (odds ratios) and standardised ratios and rates. $\mathrm{Br} M$ Med $\mathcal{F}$ 1988;296:1313-6.
(a)

35 Cox DR. Analysis of binary data. London: Chapman Hall, 1970.

36 Roth SH, Bennett RE, Mitchell CS, Hartman RJ. Cimetidine therapy in nonsteroidal anti-inflammatory drug gastropathy. Arch Intern Med 1987;147: 1798-801.

37 Porro GB, Pace F, Caruso I. Why are non-steroidal anti-inflammatory drugs important in peptic ulceration? Alimentary Pharmacology Therapeutic 1987;1(Suppl):540-7.

38 Eliakim R, Ophir M, Rachmilewitz D. Duodenal mucosal injury with nonsteroidal anti-inflammatory drugs. I Clin Gastroenterol 1987;9:395-9.

39 Graham DY, Smith JL, Dobbs SM. Gastric adaptation occurs with aspirin administration in man. Dig Dis Sci 1983;28:1-6.

40 Fok KH, George PJM, Vicary FR. Peptic ulcers induced by piroxicam. $B r$ Med I 1985;290:117.

41 Beermann B. Peptic ulcers induced by piroxicam. Br Med f 1985;290:789.

42 Meyer P, Thijs I. Peptic ulcers induced by piroxicam. Br Med f 1985;290:789.

43 Armstrong CP, Blower AL. Ulcerogenicity of piroxicam: an analysis of spontaneously reported data. Br Med f 1987;294:772.

44 Inman WHW, Rawson NSB. Peptic ulcer and piroxicam. Br Med $f$ 1985;290:932.

45 Husby G. The Norwegian multicenter study. Am $\mathcal{J}$ Med 1986;81(Suppl 5B): 6-10

46 Clinch D, Baneriee AK, Levy DW, Ostick G, Faragher EB. Non-steroidal anti-inflammatory drugs and peptic ulceration. $\mathcal{f} R$ Coll Physicians Lond 1987;21:183-7.

(Accepted 29 fune 1988)
Accident and Emergency

Department, Wexham Park

Hospital, Slough SL2 4HL

M S Christian, FRCS,

consultant in charge

\section{Incidence and implications of natural deaths of road users}

\section{S Christian}

\begin{abstract}
A prospective study was carried out over the 10 years 1978-87 to determine the incidence and implications of sudden death in road users - that is, drivers, pedestrians, cyclists, and motorcyclists. During the study period 30000 patients were seen in the same accident and emergency departments of East Berkshire after road traffic incidents or accidents, of whom 267 either were brought in dead or died within two hours after arrival. Of these patients, $64(24 \%)$ were found to have died of natural causes due to pre-existing disease or to have been killed in an incident that occurred as a result of a medical or psychiatric condition. Twelve of the patients sustained physical injury; all 64 came to necropsy. Only one incident resulted in the death of another person in addition to the natural death of a patient.

It is concluded that sudden natural death occurring in road users does not present an appreciable hazard to other road users.
\end{abstract}

\section{Introduction}

Any death or severe injury caused to road users by the sudden death of another road user in charge of a vehicle is usually followed by widespread publicity and expressions of public concern. Such cases are not common, but the implications of sudden natural death to a road user have been considered by several authorities and resulted in publications for the guidance of medical practitioners who may have to advise people of their fitness to drive. ${ }^{12}$ The incidence of natural deaths in road users does not appear to have been studied against a background of population density, types of roads serving the area, age groups, sex, and incidence of naturally occurring diseases.
This prospective study (1978-87) therefore had four objectives: (a) to determine the size of the problem; (b) to identify the degree of risk to other road users; (c) to determine the underlying pathological conditions leading to death; and (d) to consider whether in the light of the findings present advice to patients with certain medical conditions requires reassessment.

\section{Patients and methods}

Between 1 January 1978 and 31 December 1987 details were noted of all patients brought to the accident and emergency departments of East Berkshire who either were dead on arrival or died within two hours after arrival and in whom death was associated with a road "incident." As much history as possible was obtained from relatives, ambulance personnel, police, and witnesses. In particular, incidents involving only one vehicle were noted. Getting information about this category of patient was facilitated by the policy in East Berkshire of all patients apparently dead being brought into the resuscitation room, where death is confirmed after careful examination and certain basic investigations and examinations are performed authoritatively to confirm death. ${ }^{3}$ All such patients were subjected to a coroner's necropsy. Though in many cases there was a suspicion that a natural death had been a precipitating cause of the incident, the absence of severe external injury did not necessarily preclude traumatic death, nor did the presence of visible external injury indicate that trauma was an important factor leading to death.

Information from general practitioners was obtained when possible to ascertain the patients' previous medical history and drug treatments. In all cases full necropsy reports were obtained. 